\title{
Bom Retiro: 958 metros de política na poética
}

Ao chegarmos ao ponto de encontro para retirada dos ingressos de Bom Retiro 958 metros somos notificados de que seremos deslocados para um outro local onde começará o espetáculo. Quando saímos atrás de um guia, meu acompanhante, que não está acostumado com apresentações fora dos edifícios teatrais e teatro de rua, me pergunta: o espetáculo já começou? Eu dou de ombros: quem sabe? Mas é, justamente, neste trânsito entre a bilheteria e o suposto ponto a que o público é conduzido que se dá, implicitamente, o início de Bom Retiro 958 metros e se delineia, sutilmente, a nova pesquisa do Teatro da Vertigem: fazer do espaço urbano um campo de intervenção e experimentação artística.

O grupo possui uma vasta experiência em ocupação de espaços não convencionais (Igreja em Paraíso Perdido, 1992; hospital em O Livro de Jó, 1995; presídio em Apocalipse 1,11, 2000; Rio Tietê em $B R-3,2006)$, mas assimilar a cidade em sua pulsação cotidiana, incorporando ruas, esquinas, fachadas de casas e prédios, carros, ônibus, caminhões de lixo e pessoas em trânsito, em serviços ou derivas noturnas, transforma este novo espetáculo do grupo numa autêntica e original investigação em torno das ações culturais reunidas sob o conceito de site-specific.

Este aspecto sensório, artaudiano, ligado à atmosfera intrínseca do espaço de representação, é algo que sempre existiu no trabalho do Teatro da Vertigem, mas que agora ganha dinâmica, mobilidade, casualidade, perigos e surpresas. Bom Retiro 958 metros lança para o primeiro plano questões em torno do aspecto efêmero, nômade e transitório de um teatro aberto para a cidade que busca um maior engajamento com o mundo externo e a vida cotidiana.

Vamos entrando e sendo introduzidos neste cenário formado por ruas de um bairro central, de tradição têxtil, com casas e sobrados antigos, a maioria estabele- 
cimentos comerciais, quase todos escuros e silenciosos no período noturno. Lá na frente, umas três quadras adiante, alguns ônibus e carros passam, como coadjuvantes desse espaço aberto, como também, algumas pessoas que cruzam o nosso caminho e semáforos que oscilam entre o verde e o vermelho. É impossível não prestar atenção nesses pequenos focos de ação que, justamente por fazerem parte do cotidiano vivo do lugar, começam a construir um imaginário da história deste bairro, que vai se desdobrar em imagens e pedaços de situações e personagens, construídos pelo Vertigem ao longo do espetáculo.

Finalmente, nosso trajeto, curioso e desconfiado, após alguns quarteirões quase fantasmagóricos, conclui-se com o recolhimento dos ingressos e uma primeira visão que nos assegura de que "o teatro vai começar": uma mulher, sentada num pequeno banco encostado a uma parede desses sobrados, escuta uma música que sai de um pequeno objeto luminoso - um rádio ou celular.

Na sequência, surgem outras figuras, que através de pequenas ações, apontam personagens característicos do bairro: entregadores de caixas lotadas de mercadorias, uma mulher com sacolas de compras, um porteiro noturno... Um som mais potente surge por trás de uma porta pantográfica, que é aberta, revelando uma galeria de lojas de roupas e tecidos de segunda linha. Todos nós, convocados pelo som potente de uma música e por um telão luminoso, entramos para dentro deste espaço que se torna cênico por se alimentar da ambiência destas ruas fechadas, cercadas por vitrines.

Para quem conhece o trabalho do Vertigem é fácil captar a gramática e dinâmica dessa primeira parte do espetáculo: atores apresentam cenas em que constroem relações inusitadas com um determinado espaço, já existente, que é aproveitado cenograficamente (neste caso são nichos de compras, repletos de roupas, acessórios e manequins), tendo como fio condutor da ação a luz e a trilha amplificada em caixas de som distribuídas pelo espaço, que vão sinalizando o avançar do público por dentro da galeria, como também, determinando os focos de cenas para os olhos dos espectadores.

Os personagens deste momento são figuras relacionadas a este universo kitsh e, paradoxalmente, pomposo, característico deste universo comercial que reside no centro da cidade, hoje concentrado nas mãos dos imigrantes coreanos. Num pequeno shopping de roupas sem grife, de marcas desconhecidas, indivíduos periféricos valorizam os objetos e situações como se estivessem no coração do consumo mais valorizado. Uma mulher com sacolas, típica consumista obsessiva, dialoga com um 
vestido que se apresenta como o must da estação. Ela não consegue chegar a tempo de pegar a loja aberta - já fez várias tentativas, mas em vão mas em vão: a perseguição por uma escalada social está aqui sinalizada. Há também o morador de rua usuário de crack que tenta invadir a galeria e partilhar sua miserabilidade com os espectadores, que são protegidos, ostensivamente, por um segurança desqualificado, como quase sempre acontece nesses espaços públicos. Na mesma chave, surge a moça da limpeza portando sua marmita já fria, que comporta-se como a "curadora" do espaço; como também a manequim de plástico com braço defeituoso, que jamais terá direito e acesso a expor-se numa dessas vitrines em que a beleza e a perfeição são exigidas impreterivelmente. $O$ entregador de mercadorias arrisca-se num romance com as manequins expostas, como se o sexo e o amor só fossem possíveis através da relação artificial com uma boneca. Há também a radialista de óculos luminosos, sempre alardeando o universo do consumo; a costureira boliviana entrevada em sua máquina, presa ao cotidiano de panos e linhas; e a noiva paramentada para o casamento, espera infinita de uma cerimônia que nunca virá. Chamam atenção, ainda, milhares de roupas comuns jogadas ao chão que criam quase uma instalação pela qual passa o público, que se vê obrigado a pisar nesse tapete vulgar, formado por blusas, calças, vestidos, casacos e camisas...

A cena se aproveita ao máximo das possibilidades do lugar e, através da inserção de elementos criativos do grupo, desenha-se com muita graça, expertise e virtuosismo estético (música, luz e atores em perfeita sincronia), marcas registradas de Antonio Araújo e sua equipe. Mas a desolação por trás dos textos e situações não deixa dúvidas: há nesse "mercado de almas uma decrepitude e um isolamento passíveis de atenção que metaforizam - além da geografia vivencial daqueles que habitam, durante o dia, o bairro do Bom Retiro -, o próprio calvário social a que as camadas mais baixas estão sujeitas, diariamente, numa cidade como São Paulo, que faz do homem comum uma máquina de serviços e consumo.

Quando saímos de dentro da galeria para as ruas em espaços abertos, aí sim, começa a surgir a grande novidade do trabalho do Vertigem. O som agora está a cargo de um carrinho adaptado que reúne uma central de emissão e equalização, que é responsável por transmitir as falas dos atores, como também, as intervenções que criam a paisagem sonora durante o nosso percurso para caixas wireless amplificadas, dispostas nas esquinas. Técnicos estão espalhados por cada trecho de rua 
escolhido para ambientar as cenas, operando postes de iluminação como se fossem refletores, com direito a fade in e fade out. A luz também se manifesta através de interferências artificiais sobre as edificações, com efeitos diversos e projeções de imagens ou texturas visuais que incidem sobre os atores. Os técnicos estão paramentados como performers, vestidos com modelos ousados, macacões fashions, coloridos e aderentes à pele. Os atores performers atuam diante de pontos de ônibus, suspensos em muros ou varandas de apartamentos, marquises de sobrados, às vezes enquadrados por ruas inteiras.

Quando duas atrizes nuas simulam uma luta corpo a corpo num ringue improvisado de elástico numa esquina do Bom Retiro, em que carros que passam chegam a parar para conferir o que está acontecendo, uma maravilhosa inversão se opera entre os espectadores do espetáculo. É com enorme prazer que estes passam a observar esses outros espectadores desavisados e casuais, e é justamente por saberem o que os outros não sabem - eis aí o inusitado da situação - que se tira o melhor substrato cênico. Mais do que a cena é a interação da cena com o espaço e seus múltiplos espectadores (público pagante e espectador relâmpago) que sinaliza que estamos diante de algo surpreendente e provocador.

Quando um ônibus cheio de gente passa por dentro do espetáculo - que neste momento está em itinerância pela rua - e se vê obrigado a passar devagar, é impossível a nós, espectadores na situação de voyers da cidade, não buscarmos as expressões dos que estão lá, dentro do ônibus. E é na desolação dos olhares desses homens comuns, usuários de bancos lotados dos ônibus no trânsito, que sentimos a potência dramática da cidade e, paradoxalmente, a impotência de cada indivíduo, sentimento frustrante e cotidiano na vida urbana. Da mesma forma, quando atores desfilam, criticamente, como übermodels numa passarela em pleno asfalto, não somente chama a atenção a interrupção do trânsito, em que carros são forçados a aguardar que a cena termine, mas, mais sutil porém mais revelador, é o mendigo carroceiro que, em contraponto ao desfile, vasculha os latões de lixo em busca de algo que lhe seja útil. Chegamos a pensar que se trata de um ator em ação, mas de fato é a realidade social gritando em seu espaço de atuação.

Seguem-se, ainda na rua, abordagens policiais, repressão ao homoerotismo, manequins incendiados, mendigos que dormem e morrem nas calçadas, catadores de papelão, fumadores de crack, todas manifestações das misérias, anomalias e doenças do centro de São Paulo. 
Já em $B R$ - 3 o grupo iniciou sua incursão por espaços abertos, mas a ocupação do Rio Tietê fazia da cidade mais uma paisagem dinâmica que emoldurava as cenas do que uma vida pulsante que desviasse o foco da ação. Quando percorremos ruas inteiras ao longo desta segunda parte de Bom Retiro 958 metros, esse desvio ou dispersão que ocorre a partir de pequenos acontecimentos próprios do lugar é quase constante, mas incide na cena de forma orgânica e natural, complementando ou entrando em choque com as ações construídas pelo grupo. Mais do que interrupção, trata-se de assimilação: o Vertigem executa uma intervenção cênica que respira e pulsa conjuntamente com o cotidiano usual daquele espaço urbano, tornando indivisível o trabalho de criação do grupo com o conteúdo inerente ao local de apresentação.

Quando somos colocados diante da fachada do TAIB, Teatro de Arte Israelita Brasileiro, poucos têm a dimensão de que lugar é este. É aí a passagem para a terceira e última parte do espetáculo. O público é introduzido no hall em que se senta nas escadarias do teatro. Jogados nos degraus, papéis revelam outras informações para os espectadores mais curiosos: eu peguei um sobre a peça de estreia do teatro em 1960 meu acompanhante pegou outro sobre El Dibuk Tronik, personagem diabólico do século XIX, escrito por Scholem Aleichem, nome, também, da escola de tradição judaica que funcionou no mesmo local durante quatro décadas.

$\mathrm{Na}$ sequência somos introduzidos na plateia do teatro, uma área que carrega consigo os mais de vinte anos de abandono do lugar. O TAIB foi um dos teatros mais privilegiados de São Paulo, mas com a migração da comunidade judaica para outros bairros, e também, tendo sofrido perseguições por seu caráter contestatório na época da ditadura, caiu no esquecimento. $O$ cheiro de mofo é intenso e a plateia, semidestruída, ainda conserva algumas cadeiras velhas nas quais os espectadores se colocam. A desolação e insalubridade são impressionantes. Surge, ainda na semiobscuridade, um coro de viciados em crack que coreografam, no palco, a dança do consumo de drogas. A consumista consegue finalmente ser presenteada, por figuras da moda up to date, com o vestido tão desejado que, numa metáfora fáustica, é lambido pelas chamas. O público é convocado a subir no palco, o que causa um medo enorme, pois a sensação é de que o estado precário do piso suspenso de madeira não vai nos aguentar. De lá, nos voltamos para a plateia e surgem várias costureiras trabalhando em suas máquinas, numa paisagem visual e sonora que sintetiza todo o esforço de sobrevivência por parte dos trabalhadores braçais, enquanto uma chuva de retalhos caem sobre nós, pedaços 
de vidas e histórias, cortados em triângulos. Por fim, um grupo de agentes sanitários começa a invadir o local com água e sabão, enxotando-nos dali, fisicalizando a higienização social por que passa a nossa cidade nos últimos anos.

Na saída do teatro, como fechamento do espetáculo, uma caçamba nos aguarda em que a manequim defeituosa e a faxineira filósofa encontram-se dispostas em meio ao entulho, numa alusão ao tratamento igualitário e cruel atribuído pela cidade às pessoas e às coisas, como se tudo tivesse de ser "tirado da frente", rápida e sem critérios, como lixo e descarte urbano.

A dramaturgia de Joca Reiners Terron é fragmentada, cifrada, de difícil assimilação pelo público. Dificulta o nosso entendimento deste patchwork formado por pequenos momentos e metáforas do cotidiano das pessoas e dos espaços do Bom Retiro, resultado escrito do substrato dramatúrgico levantado pelo grupo durante sua ocupação por mais de dois anos no bairro. O processo envolveu seminários e palestras, oficinas de criação, workshops e "derivas", caminhadas solitárias e notívagas dos integrantes da equipe pelas ruas da região.

Mas o fato é que a dramaturgia cênica de Antônio Araújo é de uma potência avassaladora, elaborada através de um processo colaborativo em parceria com seu mais antigo colaborador, o iluminador Guilherme Bonfanti, que realiza o trabalho artístico mais admirável de sua carreira, agora em parceria com Grissel Piguillem na projeção de imagens; seus atores da antiga formação Luciana Shwinden e Roberto Áudio; somados a participação de Erico Theobaldo e Miguel Caldas na trilha original, com o suporte logístico e técnico de Kako Guirado; as coreografias de Renata Melo e a presença inusitada do estilista Marcelo Sommer, além de uma dezena de jovens parceiros de criação, novos técnicos de operação e o suporte de uma linha de frente de produção - encabeçados por Henrique Mariano e Stella Marini -que têm a difícil função não só da montagem mas, bem mais árdua, de desproduzir o espetáculo a cada dia de apresentação.

Antônio Araújo é um artista de trajetória peculiar. Suas imagens inesquecíveis; sua escritura tortuosa e, paradoxalmente, ritualística; sua capacidade de trânsito entre as artes; seu poder de compartilhamento de criação com sua equipe; sua força de produção; sua capacidade de articulação na cultura; seu comprometimento com a contemporaneidade; seu embasamento teórico; sua prática acadêmica; sua expansão profissional pela Europa; todo esse arsenal de particularidades fazem dele um dos 
homens do teatro paulista mais admirados nas últimas duas décadas. É, também, um dos artistas que mais poetiza as questões emergentes da nossa sociedade.

A arte, não importa como se apresente, é intrinsecamente política. E apesar de Antonio Araújo não se colocar como porta-voz do teatro político e mesmo que a força imagética de suas encenações seja maior do que qualquer mensagem, a atuação do Teatro da Vertigem nunca estará a serviço do teatro comercial ou de questões estéticas ou de conteúdo voltadas aos temas supérfluos das elites, pelo contrário. Está presente em sua obra, cada vez mais, uma crítica à cultura paulistana e brasileira, que inclui reflexões e engajamentos em torno dos espaços não especializados e públicos, instituições marginalizadas, problemas sociais urgentes e lugares relegados ao esquecimento e a degradação. Preocupados em fortalecer a capacidade do teatro de penetrar na organização sociopolítica da vida contemporânea com maior impacto e significado, o Vertigem teatraliza temas como moradia na rua, degradação nas drogas, homofobia, embate étnico, repressão policial, consumismo e artificialismo, incomunicabilidade, eugenia....

A preocupação artística jamais é relegada ao segundo plano e talvez seja essa força criativa e visual - a potência da elaboração e escritura cênica -, que façam emergir falsas leituras do trabalho de Antonio Araújo e o Vertigem, que chegam a falácia de identificar ausência de atuação política no espetáculo.

Segundo o Dicionário Houaiss, a palavra engajamento significa, entre outras coisas, "participação ativa em assuntos e circunstâncias de relevância política e social, passível de ocorrer por meio de manifestação intelectual pública, de natureza teórica, artística ou jornalística."

Eleger o bairro do Bom Retiro como algo mais do que um lugar, proporcionando uma maior visibilidade e alertando para a emergência de focarmos nossa atenção para aquilo que nossas vistas buscam evitar - embates étnicos de minorias imigrantes, moradias de excluídos sociais, levantamento de histórias reprimidas e espaços abandonados - significa, obviamente, engajamento e politização.

Mas, certamente, sob a assinatura de Antonio Araújo, a mensagem jamais virá mastigada ou vai atrelar-se, explicitamente, a grupos ou intelectuais que acreditam que somente através do distanciamento brechtiano e do protesto e denúncia alinhados é que a ação política do teatro pode e deve se manifestar. Sou da opinião de que tornar poética a cena e "vertiginar" o espectador é mais efetivo politicamente. 
Eu que estive por dentro do grupo, em sua origem, sei como é difícil resistir e permanecer num projeto em que o teatro está acima de todas as coisas. Trabalhar com Tó Araújo não é só atuar: é fazer parte de uma gincana de criação e de produção que pode durar uma eternidade; amalgamar no coletivo; escolher a miséria como objeto de arte e situação de existência; andar descalço, literalmente, por sobre ratos e baratas; acreditar no impossível!

O Teatro da Vertigem percorre 958 metros para colocar uma lente de aumento sobre um Bom Retiro já afastado de seus áureos tempos. Mas, a frente de tudo, permanece e se aprimora a linguagem do grupo, que trata de questões emergentes da nossa sociedade a partir de uma manifestação poética que não deixa dúvidas sobre o seu valor artístico, nos revelando assim, mais uma vez, as razões que o tornam um dos coletivos mais respeitados em nosso teatro. 